\title{
Bacteria in milk from anterior and posterior mammary glands in sows affected and unaffected by postpartum dysgalactia syndrome (PPDS)
}

\author{
Nicole Kemper* and Imke Gerjets
}

\author{
Address: Institute of Animal Breeding and Husbandry, Christian-Albrechts-University Kiel, Olshausenstraße 40, D-24098 Kiel, Germany \\ Email: Nicole Kemper* - nkemper@tierzucht.uni-kiel.de; Imke Gerjets - igerjets@tierzucht.uni-kiel.de \\ * Corresponding author
}

Published: 22 June 2009

Acta Veterinaria Scandinavica 2009, 51:26 doi:10.1186/175I-0147-5I-26

This article is available from: http://www.actavetscand.com/content/5I/I/26

(C) 2009 Kemper and Gerjets; licensee BioMed Central Ltd.

This is an Open Access article distributed under the terms of the Creative Commons Attribution License (http://creativecommons.org/licenses/by/2.0), which permits unrestricted use, distribution, and reproduction in any medium, provided the original work is properly cited.
Received: 8 December 2008

Accepted: 22 June 2009

\begin{abstract}
Background: The performance of piglet weight gain is strongly dependent on the sow's ability to meet the demand for adequate milk. Postparturient disorders, especially those subsumed under the term postpartum dysgalactia syndrome (PPDS), can alter or reduce the milk production sensitively, resulting in starving piglets. The aim of this study was to gather further information about the prevalence of different bacterial species in the anterior and posterior mammary glands of sows with respect to the clinical appearance of PPDS.

Methods: In this study, the health status of 56 sows after farrowing was determined with special regard to mastitis and dysgalactia. Pooled milk samples from anterior and posterior glands were taken from both affected and non-affected animals and analysed bacteriologically for the presence of a wide spectrum of different pathogens.

Results: Mainly Escherichia coli, staphylococci and streptococci were detected in high percentages but without significant differences in healthy and diseased animals and anterior and posterior glands. However, the large percentages of coliform bacteria suggested a transmission route via faecal contamination.

Conclusion: In this study, the prevalence of different bacteria in anterior and posterior glands in PPDS positive and negative sows was analysed. No significant differences in bacteria of healthy and diseased sows were assessed. Therefore, the development of clinical PPDS and actual infection seems to be largely dependant on individual resistance in single sows.
\end{abstract}

\section{Background}

In their first days of life, piglets are totally reliant on the sow for access to colostrum and milk. Every alteration in both milk yield and composition has highly sensitive impacts on weight gain and growth rate. Therefore, postparturient disorders, including dysgalactia in sows, are a very important disease complex economically [1]. They are reported world-wide, but subsumed under different terms depending on the geographical location. While mastitis, metritis and agalactia syndrome (MMA) $[2,3]$ is the commonly used name in European countries, postpartum dysgalactia syndrome (PPDS or PDS) [4] has become widely accepted in English-speaking areas. At farm level, incidence is estimated to differ between $0.5 \%$ and $60 \%$ [5], with an average incidence of about $13 \%$ [611]. The syndrome is characterised by greatly reduced 
milk production within 12 to 48 hours post-partum that rapidly leads to piglet starvation. Even though metritis is often a part of the syndrome, mastitis is the central symptom, as shown by several studies [12-14]. The bacteria most frequently isolated from mastitis-affected sows belong to the class of coliforms [13-17]. Bacterial genera included in the class of coliforms are represented by Escherichia, Enterobacter, Citrobacter, and Klebsiella. Several successful infection experiments leading to mastitis in sows have demonstrated the predominant role of these organisms [13,18]. Mastitis is a clear pathological entity: infected glands typically show signs of inflammation such as severe oedema and skin congestion [4], and, with many glands involved, sows develop fever $\left(>40.3^{\circ} \mathrm{C}\right)$ and lose their appetites [18-20]. Mastitis can be a local process, restricted to one or several glands, but can also affect all mammary complexes [4]. Pathological foci of mastitis were detected as well in anterior complexes as in posterior complexes, but severe changes were more present in the latter [20]. These findings were supported by Bostedt et al. [21] and Baer and Bilkei [22], showing that posterior glands were more prone to pathological changes compared with anterior ones. However, detailed investigations on the bacteriological findings in cranial and caudal mammary glands and the possible consequences have not yet been reported. Therefore, the presence of bacteria in mammary glands of different location was examined in this study with special regard to the clinical status of the sow post partum.

\section{Methods \\ Animals}

In our study, 56 primiparous or multiparous Large White and cross-bred sows, taking part in an experiment on injected temperature transponders and water intake [16], were investigated. The study took place in a time period of six months between December 2007 and May 2008. Sows were housed at the institute's research farm with 120 sows in total. They were managed in a three-week rhythm with a 28-day lactation period. At average, the sampled animals were in their $2,9^{\text {th }}$ parity. Sows were defined as PPDS-positive due to a combination of appropriate criteria: with a rectal temperature higher than $39.5^{\circ} \mathrm{C}$ within 12 to 24 hours post-partum, and in addition, detectable inflammation in the mammary gland, and/or diminished appetite and/or altered piglet behavior $[1,12]$. Inflammation was diagnosed by a veterinarian, observing the typical signs of inflammation, such as severe edema, hardening, and skin congestion. Altered piglet behavior was present when piglets show vigorous nursing efforts, decrease their attempts to nurse and their general activity, retreat to the warmest parts of the farrowing crate or lose weight.

\section{Bacteriology}

After assessment of the PPDS status, the teats were cleaned with soap solution and disinfected with 70\% isopropyl alcohol (Universal Hospital Supplies LTD, Enfield, UK). Milk samples from all animals were milked on transport swabs with Amies medium (Transwab, Medical Wire \& Equipment, Corsham, UK) after oxytocin injection (30 I.E. i.m.). This oxytocin dosage was chosen after pre-tests on the minimum dosage followed by milk ejection, and also recommended by Morkoc [23]. Piglets were removed before the washing procedure, and five minutes after injection, milking was started. The first streams of secretion from each teat were discarded in order to 'wash out' bacteria in the distal end of the teat canal. Specimens were transported to the laboratory within two hours and pooled. Pooling was performed by incubating all samples of one animal from the anterior mammary complex, subsuming the first three pairs of pectoral glands, for enrichment in one tube $(50 \mathrm{~mL})$ with casobuillon (Roth GmbH\&Co KG, Karlsruhe, Germany). Samples from the three to four following pairs of caudal glands were pooled likewise. Consequently, a sample pair consisting of pooled milk swabs from anterior and posterior glands had to be examined for each sow. In total, 112 pooled samples ( 56 from anterior and 56 from posterior glands) were analysed. After 24 hours of incubation at $37^{\circ} \mathrm{C}$, bacteriological routine diagnostic procedures including selective enrichment and biochemical confirmation (API20E, bioMérieux, Nürtingen, Germany) took place as described previously for Enterobacteriaceae, especially Escherichia coli (E. coli), Klebsiella species (spp.), Enterobacter spp., Citrobacter spp., and Salmonella spp. [24]. Staphylococci were isolated via incubation in CSL-Bouillon (Roth GmbH\&Co KG) $\left(37^{\circ} \mathrm{C}, 24 \mathrm{~h}\right)$ and streaking out on Sheep Blood Agar (Oxoid GmbH, Wesel, Germany) $\left(37^{\circ} \mathrm{C}, 24 \mathrm{~h}\right.$ ), followed by Gram-staining and Catalase-testing (Merck KGaA, Darmstadt, Germany) and biochemical identification (ID32Staph, bioMérieux). For Streptococci, incubation was performed in the same way and biochemical identification was done with API20Strep (bioMérieux).

\section{Statistical analysis}

For statistical analysis, the Fisher's Exact Test was performed using the procedure PROC FREQ from the SAS statistical software (SAS, 2003). In general, a statistical significance level of $\mathrm{p} \leq 0.05$ was used.

\section{Results}

According to the definition of PPDS affection, 27 sows (48.2\%) out of the total number of 56 animals were positive. Consequently, 29 milk sample pairs from negative sows (51.8\%) were available for investigation. From all sows, one or more different bacteria were isolated at least in one of the two pooled samples. In total, 159 bacteria isolates were detected. From PPDS-affected sows, 84 iso- 
lates were proven in anterior (43 isolates) and posterior samples (41 isolates), while 75 were present in anterior (47 isolates) and posterior ( 28 isolates) samples from non-affected sows. In both PPDS-affected and nonaffected sows, no bacteria were detected in $18.5 \%$ (PPDS+) and $13.8 \%$ (PPDS-) of pooled samples from anterior glands and in $25.9 \%$ (PPDS+) and $34.5 \%$ (PPDS) from posterior mammary glands (Table 1 ). This percentage was increased in the posterior glands in PPDS-negative sows. Furthermore, posterior mammary glands in negative sows showed the lowest variety of bacterial species. The isolated species belonged to the families Enterobacteriaceae, Staphylococcaceae, Streptococcaceae, and Enterococcaceae (Table 2). Escherichia coli, Staphyloccocus spp. and Enterococcus spp. were the predominant bacteria species. From the genus Staphyloccocus (Staph.), Staph. aureus and Staph. hyicus were considered in the following analysis at species level. Genera found only in very low numbers were subsumed as 'others', and included Aerococcus spp., Enterobacter spp., Escherichia spp., Lactobacillus spp., Leuconostoc spp., Raoultella spp., and Streptococcus spp.. Due to the possible importance as a pathogen, Klebsiella spp. were specially mentioned. After statistical analysis, only the percentages of Staph. aureus and Staph. hyicus differed significantly with regard to the mammary gland location (Table 3). This is, however, related to the low prevalence of these species (Staph. aureus: $\mathrm{n}=14 ;$ Staph. hyicus: $\mathrm{n}=6$ ). The comparison of the bacterial occurrence in all samples of PPDS-affected and non-affected sows showed no significant influences of the PPDS status on the bacterial flora with the exception of Staph. spp., showing significant differences with respect to the PPDS status (Table 4). The distribution of the different bacteria in anterior and posterior pooled samples from PPDSaffected and non-affected sows is shown in Figure 1.

\section{Discussion}

The aim of this study was to gather further information about the prevalence of different bacterial species in the anterior and posterior mammary glands of sows with respect to the clinical appearance of the PPDS syndrome. This clinical appearance is usually diagnosed via rectal temperature measuring post-partum [25] and sows are defined as 'PPDS-positive' when a certain threshold is exceeded. This threshold is defined rather coincidentally between $39.3^{\circ} \mathrm{C}$ and $40.5^{\circ} \mathrm{C}[3]$ and the use of it might be regarded as critical since physiological hyperthermia is often observed in sows, leading to misinterpretations $[4,16]$. To avoid confusion with this physiological temperature increase and to reduce the administration of antibiotics in non-affected animals, a threshold of $39.5^{\circ} \mathrm{C}$ in the time frame 12 to 24 hours post-partum is recommended. Furthermore, diagnosis should be performed not only due to temperature increase, but due to a combination of appropriate criteria such as clinical mammary gland changes, diminished milk production and reduced appetite [26]. Other parameters like cell count, established for cows' milk, are not common for diagnosis and data on thresholds are rare. For instance, a threshold of 5 $\times 10^{6}$ cells per $\mathrm{mL}$ was proposed by Bertschinger and Bühlmann [27], while Persson et al. [28] suggested $10 \times 10^{6}$ cells per $\mathrm{mL}$.

The procedure of milking sows in order to obtain samples is difficult and severely restricted by practical circumstances, but an absolutely needed prerequisite to obtain reliable results. Cleaning and disinfection are urgently required to eliminate skin flora or other contaminating microorganisms. Examinations on the skin flora on sows' teats do not exist, but studies on cows suggest, that staphylococci are the most common bacteria $[29,30]$. Pooled milking, as it is often used to get a sufficient amount of milk, most likely increases the risk of contamination. Because of this, and because of economic reasons, single teat samples from anterior and posterior glands were taken separately in our study, but pooled in the next laboratory step. In this way, the expected costs for bacteriological differentiation were reduced, while maintaining the hygienic demands. Moreover, the anatomy of the mammary gland can influence sampling: per teat, two complete gland systems end in two teat orifices without muscular sphincters [4]. Therefore, if only one gland system is affected by mastitis, the sampled milk might only consist of secretion from the other, healthy system, leading to false negative results.

Bacteria were found in all sows, but not necessarily in both anterior and posterior samples. Compared to similar

Table I: Number of different bacteria species isolated in samples from PPDS-affected and non-affected sows

\begin{tabular}{|c|c|c|c|c|c|c|c|c|c|c|c|c|}
\hline \multirow[b]{2}{*}{ Number of isolated different bacteria species } & \multicolumn{6}{|c|}{$\begin{array}{l}\text { Pooled samples from anterior mammary glands } \\
\text { (first } 3 \text { pairs of cranial glands) }\end{array}$} & \multicolumn{6}{|c|}{$\begin{array}{l}\text { Pooled samples from posterior mammary glands } \\
\qquad(3-4 \text { pairs of caudal glands })\end{array}$} \\
\hline & 0 & I & 2 & 3 & 4 & 5 & 0 & 1 & 2 & 3 & 4 & 5 \\
\hline In samples from PPDS+ sows $(n=27)(\%)$ & 18.5 & 29.7 & 25.9 & 25.9 & 0.0 & 0.0 & 25.9 & 25.9 & 25.9 & 18.5 & 0.0 & 3.8 \\
\hline In samples from PPDS- sows $(n=29)(\%)$ & 13.8 & 37.9 & 31.0 & 10.3 & 3.5 & 3.5 & 34.5 & 34.5 & 31.0 & 0.0 & 0.0 & 0.0 \\
\hline
\end{tabular}


Table 2: Numbers of isolated bacteria in all samples $(n=|| 2)$

\begin{tabular}{|c|c|c|c|c|c|c|c|}
\hline \multirow[t]{2}{*}{ Enterobacteriaceae } & \multirow{2}{*}{\multicolumn{2}{|c|}{ Staphylococcaceae }} & \multirow[b]{2}{*}{$\mathrm{n}$} & \multirow[t]{2}{*}{ Streptococcaceae } & \multicolumn{3}{|c|}{ Enterococcaceae } \\
\hline & & & & & $\mathrm{n}$ & & $\mathrm{n}$ \\
\hline Enterobacter sp. & 2 & Staph*. aureus & 14 & Aerococcus urinae & 4 & Ec*. avium & 2 \\
\hline Escherichia coli & 47 & Staph. capites & 1 & Aerococcus viridans & 3 & Ec. durans & 16 \\
\hline Escherichia vulneris & 2 & Staph. chromogenes & 2 & Aerococcus sp. & 2 & Ec. faecalis & 3 \\
\hline Klebsiella oxytoca & I & Staph. equorum & I & Lactococcus lactis & 2 & Ec. faecium & 9 \\
\hline Klebsiella pneumoniae & I & Staph. hyicus & 6 & Str*. bovis & I & Ec. sp. & 9 \\
\hline \multirow[t]{5}{*}{ Raoultella ornithinolytica } & I & Staph. lentus & I & Str. equinus & I & & \\
\hline & & Staph. saprophyticus & 1 & Str. mitis & 2 & & \\
\hline & & Staph. simulans & 14 & Str. mutans & I & & \\
\hline & & Staph. warneri & 1 & Str. sp. & 5 & & \\
\hline & & Staph. sp.** & 5 & & & & \\
\hline
\end{tabular}

*Staphylococcus (Staph.), Streptococcus (Str.), Enterococcus (Ec.)

** not further identified

studies, for instance Persson et al. [28] with no bacterial growth in $10 \%$ of all samples from agalactic and in $54 \%$ of all samples from healthy sows, this prevalence is high. However, in contrast to our project, no enrichment step was included in the bacteriological examination in that study, but samples were spread directly on blood agar. No selective agars were used, also lowering the probability to detect certain species. Moreover, in comparison to other studies [6,9-11], the documented incidence at farm level on the research farm was high with $48.2 \%$. The general high incidence on farm level and the unknown background of that fact were reasons to realise this study. After antibiotic treatment in combination with non-steroidal anti-inflammatory drugs, administered after sampling, all sows recovered. One important fact regarding the actual

Table 3: P-values of the effects 'PPDS-status' and 'mammary gland location' on the occurrence of different bacteria species in samples from PPDS-affected and non-affected sows $(n=|| 2)$

\begin{tabular}{lll}
\hline & PPDS status & Mammary gland location \\
\hline E. coli & 0.13 & 0.13 \\
\hline Staph. aureus & 0.18 & $\mathbf{0 . 0 2}$ \\
\hline Staph. hyicus & 0.33 & $\mathbf{0 . 0 1}$ \\
\hline Staph. spp.* & $\mathbf{0 . 0 4}$ & 0.14 \\
\hline Enterococcus spp. & 0.16 & 0.15 \\
\hline Klebsiella spp. & 0.23 & 0.51 \\
\hline others* & 0.18 & 0.19 \\
\hline
\end{tabular}

significant effects $(\leq \mathbf{0 . 0 5})$ in bold

* all Staph. species but Staph. aureus and Staph. hyicus

** Aerococcus spp., Enterobacter spp., Escherichia spp., Lactobacillus spp.,

Leuconostoc spp., Raoultella spp., Streptococcus spp. presence of different bacteria species in sows' milk and the comparison with former investigations, conducted mainly in the 1980s and 1990s [31], is the use of appropriate methods for identification. Most isolated bacteria in our study were representatives of the families Enterobacteriaceae, Staphylococcaceae, Streptococcaceae, and Enterococcaceae. This spectrum is in agreement with other studies $[15,32]$; for instance, in a bacteriological examination of mammary gland changes in 663 sows suffering mastitis, mainly E. coli and Klebsiella spp. were detected, but also Streptococci and Staphylococci [22].

Like in other studies, the most commonly isolated bacteria from mastitis-affected sows belong to the class of coliforms, covering the bacterial genera Escherichia, Klebsiella, Enterobacter and Citrobacter $[13,15,17]$. Subsequently, the predominant role of coliform bacteria was clearly shown by Wegmann et al. [14]; in 131 complexes with mastitis, E. coli and Klebsiella pneumonia were isolated in 79\%. This importance of $E$. coli has been confirmed in several studies $[13,33,34]$ and in infection experiments, provoking clinical and haematological changes comparable to natural infections $[35,36]$. To emphasize the role of coliforms and to end the confusing terminology, the term 'coliform mastitis' was suggested for peripartal mastitis in sows [1].

Bacteria causing or at least accompanying the syndrome of coliform mastitis may originate from the intestinal flora of the sow, from the environment or from the oral flora of the neonatal piglet. The hypothesis of a galactogenous route of infection was corroborated by experiments carried out by Bertschinger et al. [15], in which a reduction of PPDS prevalence could be noticed after protection of the mammary gland against faecal contamination. Therefore, faecal contamination was postulated to be of paramount importance as a cause of puerperal mastitis. The faecal origin of $E$. coli isolated from sows' milk was also reported by Awad Masalmeh et al. [15]: in one quarter of 
Table 4: Percentage of isolated bacteria species in the total number of samples $(n=1 \mid 2)$ from PPDS-affected and non-affected sows

\begin{tabular}{lccc}
\hline & percentage in samples $(\mathrm{n}=54)$ from PPDS+ sows $(\%)$ & percentage in samples $(\mathrm{n}=58)$ from PPDS- sows $(\%)$ & P-values \\
\hline E. coli & 38.9 & 44.8 & 0.13 \\
\hline Staph. aureus & 14.8 & 10.3 & 0.18 \\
\hline Staph. hyicus & 11.1 & 10.3 & 0.32 \\
\hline Staph. spp.* & 29.6 & 15.5 & 0.04 \\
\hline Enterococcus spp. & 33.3 & 31.0 & 0.16 \\
\hline Klebsiella spp. & 3.7 & 0.0 & 17.2 \\
\hline others** & 20.4 & 0.23 \\
\hline
\end{tabular}

significant effects $(\leq 0.05)$ in bold

* all Staph. species but Staph. aureus and Staph. hyicus

** Aerococcus spp., Enterobacter spp., Escherichia spp., Lactobacillus spp., Leuconostoc spp., Raoultella spp., Streptococcus spp.

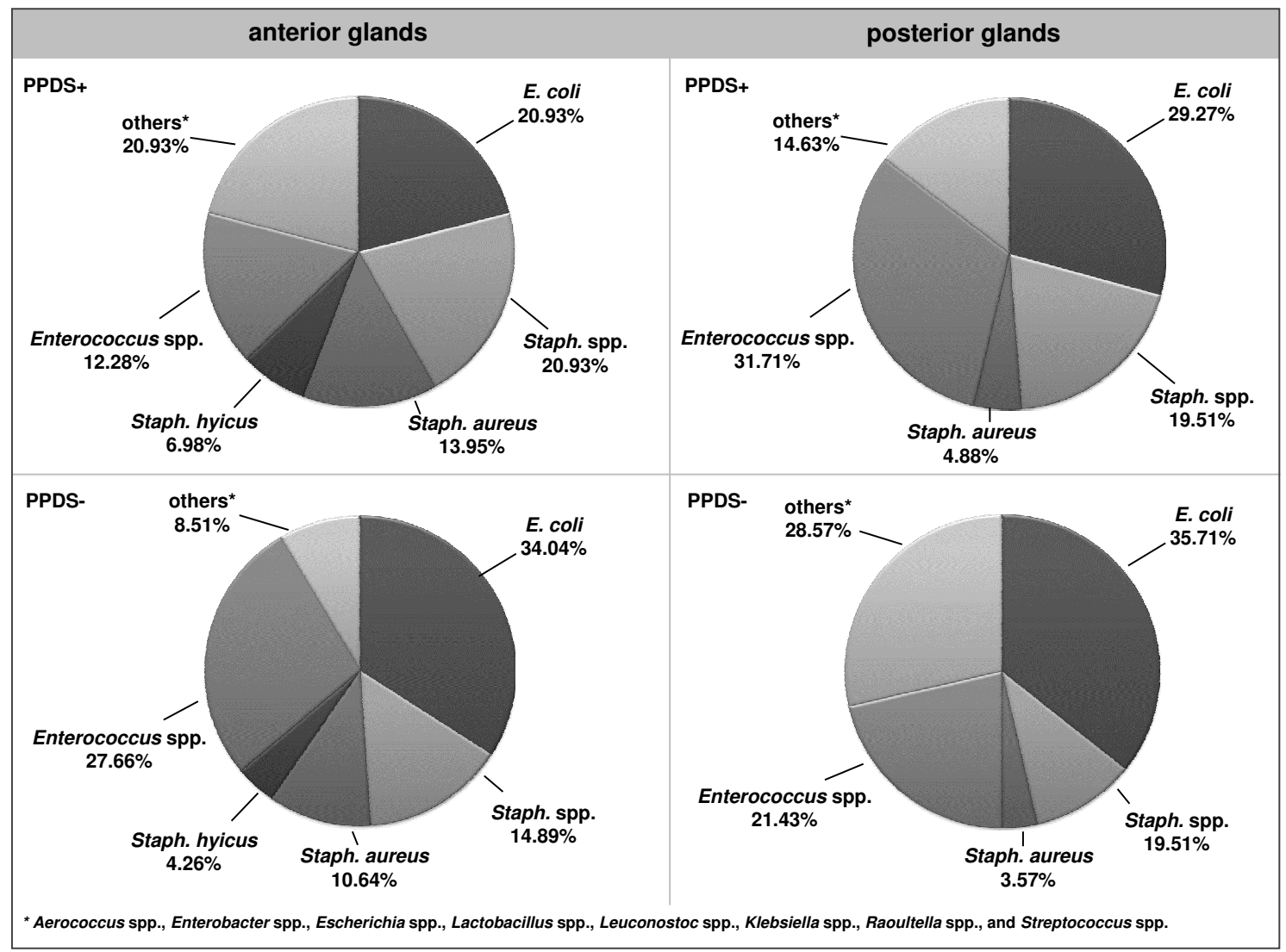

Figure I

Bacterial spectrum in samples from anterior and posterior glands from PPDS-affected $(n=27)$ and $n o n-$ affected sows $(n=29)$. 
67 PPDS-affected sows O-serogroup-identical E. coli were detected in both milk and faecal samples. In another study comparing the bacterial flora of the uterus, the caecum, the ileum and the mammary gland, the prevalence of only gram-negative bacteria in the mammary glands and in the ileum of CM-affected sows was remarkable [23]. However, in this study, the faecal route of infection could not be confirmed due to the study design.

The lack of gram-negative bacterial culture growth in uterine samples supports the theory that uterine involvement in PPDS is of minor importance, as has been suggested in several studies [37-39]. However, infections of the urinary tract are strongly related to puerperal diseases, even though urinary infections are not apparent clinically [40]. In these infections as well, the most common organism associated with bacteriuria was found to be E. coli [41]. Therefore, not only faecal, but also urine contamination has to be considered as an infection source for PPDS. In this context, Bertschinger [1] suggested that the often recommended feed reduction might not act directly in the sow's organism, but indirectly through reduced exposure of the mammary complexes due to decreased amounts of faeces and urine contaminating the lying area. Up to now, information on the actual influences leading to the manifestation of mastitis in sows is widely lacking and further research is desirable.

\section{Conclusion}

This study examines the prevalence of different bacteria in anterior and posterior glands in PPDS positive and negative sows. In conclusion, the bacterial flora of PPDSaffected and non-affected sows differs only slightly. Mainly ubiquitous bacteria were isolated and significant differences in the occurrence in anterior and posterior glands were not statistically confirmed. At the current state of knowledge, the reason for only some sows developing clinical signs of infection after contact with these ubiquitous bacteria remains unknown. The immune response and the actual outbreak of infection seems to depend on the immunological reactivity of the sow. Hence, one may hypothesise that developing clinical PPDS is largely dependant on the individual resistance of the sow and research is needed to define this individual resistance in detail.

\section{Competing interests}

The authors declare that they have no competing interests.

\section{Authors' contributions}

NK designed and coordinated the study, draft the manuscript and participated in the bacteriological analysis. IG carried out the bacteriological examinations and performed the statistical analysis. All authors read and approved the final manuscript.

\section{Authors' information}

NK, Dr. med. vet, is Certified Veterinary Specialist in Microbiology (Fachtierärztin Mikrobiologie) and in Animal Hygiene (Fachtierärztin Tierhygiene) and leader of the researchgroup 'geMMA: structural and functional analysis of the genetic variation of the MMA-sydrome' (www.gemma-kiel.de). IG, MSc. Agr., is researcher in this group.

\section{Acknowledgements}

This work was partially financially supported by the Federal Ministry of Education and Research (BMBF) in the research programme 'FUGATO - Functional Genome Analysis in Animal Organisms', project 'geMMA: structural and functional analysis of the genetic variation of the MMA-syndrome' (FKZO3 15/38). The authors thank Stephan Kruse for assisting this study by helping with the sows' milking, Jens Wolfmüller for excellent technical assistance and Dr. Carsten Henze for statistical advice.

\section{References}

I. Bertschinger HU: Coliform Mastitis. In Diseases of Swine 8th edition. Edited by: Straw BE, D'Allaire S, Mengeling WL, Taylor DJ. Ames: lowa State University Press; 1999:457-464.

2. Martin $\mathrm{CE}$, Hooper $\mathrm{BE}$, Armstrong $\mathrm{CH}$ : A clinical and pathological study of the mastitis-metritis-agalactia syndrome of sows. J Am Vet Med Assoc 1967, I5 I:1629-1634.

3. Waldmann K-H, Wendt M: Lehrbuch der Schweinekrankheiten 4th edition. Stuttgart: Parey Verlag; $200 \mathrm{I}$.

4. Klopfenstein C, Farmer C, Martineau GP: Diseases of the mammary glands and lactation problems. In Diseases of swine 9th edition. Edited by: Straw BE, Zimmermann JJ. Taylor DJ: lowa State University Press; 2006:833-860.

5. Hirsch AC, Philipp H, Kleemannm R: Efficacy of meloxicam for treatment of the mastitis-metritis-agalactia syndrome in sows. Prakt Tierarzt 2004, 85:842-848.

6. Bäckström L, Morkoc AC, Connor J, Larson R, Price W: Clinical study of mastitis-metritis-agalactia in sows in Illinois. J Am Vet Med Assoc 1984, 185:70-73.

7. Hermannson I, Einarsson S, Larsson K, Bäckström L: On the agalactia postpartum in the sows: a clinical study. Nord Vet Med. 1978, 30(I I):465-473.

8. Jorsal SE: Epidemiological and statistical analysis of disease records from pig testing stations. PhD-Thesis University of Copenhagen; 1983.

9. Krieter J. Presuhn U: Genetische Parameter für die Behandlungsfrequenz beim MMA-Syndrom (Genetic parameters for MMA treatment in sows). Züchtungskd 2009, 81 : I 49-154.

10. Madec F, Josse J: Le pathologie de la parturition chez le truie: étude épidemiologigique dans cinq élevages (Pathology of the parturition of the sow: epidemiological studies on five farms). Rec Med Vet 1992, 68:340-349.

II. Thorup F: Effect of treatment for MMA - retrospective observations. 17th International Pig Veterinary Society Congress Melbourne, Australia 2000:97.

12. Heinritzi K, Hagn J: Untersuchungen zur Wirksamkeit und Verträglichkeit des neu entwickelten Cephalosporins Cefquinom bei an puerperaler Septikämie und Toxämie erkrankten Sauen (Comparison of therapeutic performance of the new Cephalosporin Cefquinome with other treatment regimes in gilts with puerperal septicaemia and toxaemia syndrome). Tierärztl Prax 1999, 27:1 I4-121.

13. Ross RF, Orning AP, Woods RD, Zimmermann BJ, Cox DF, Harris $\mathrm{DL}$ : Bacteriologic study of sow agalactia. Am J Vet Res I98I, 42:949-955.

14. Wegmann $\mathrm{P}$, Bertschinger $\mathrm{HU}$, Jecklin $\mathrm{H}$ : A field study on the prevalence of coliform mastitis (MMA syndrome) in Switzerland and the antimicrobial susceptibility of the coliform bacteria from the milk. 8th International Pig Veterinary Society Congress, Barcelona, Spain 1986:92.

15. Awad Masalmeh M, Baumgartner W, Passering A, Silber R, Hinterdorfer F: Bakteriologische Untersuchungen bei an puerperaler 
Mastitis (MMA-Syndrom) erkrankten Sauen verschiedener Tierbestände Österreichs (Bacteriological studies in sows with puerperal mastitis in different herds in Austria). Tierärztl Umsch 1990, 45:526-535.

16. Gerjets I, Kruse S, Krieter J, Kemper N: Diagnosis of MMA affected sows: bacteriological differentiation, temperature measurement and water intake. 20th International Pig Veterinary Society Congress, Durban, South Africa 2008:236.

17. Hirsch AC, Philipp H, Kleemann R: Investigation on the efficacy of meloxicam in sows with mastitis-metritis-agalactia syndrome. J Vet Pharmacol Ther 2003, 26:355-360.

18. Bertschinger HU, Bürgi E, Eng V, Wegmann P: Lowering of the incidence of puerperal mastitis in the sow by protection of the mammae from contamination. Schweiz Arch Tierheilkd 1990, 132:557-566.

19. Halgaard C: Epidemiologic factors in puerperal diseases of sow. Nord Vet Med. 1983, 35(4):161-174.

20. Middleton Williams DM, Pohlenz J, Lott-Stolz G, Bertschinger HU: Untersuchungen über das Mastitis-Metritis-Agalactie-Syndrom (Milchfieber) der Sau (Investigations on the mastitis metritis agalactia syndrome (milk fever) in sows). Schweiz Arch Tierheilkd 1977, I 1 9:214-223.

21. Bostedt H, Maier G, Herfen K, Hospen R: Clinical examinations on gilts with puerperal septicaemia and toxaemia. Tierarztl Prax Ausg G Grosstiere Nutztiere. 1998, 26(6):332-338.

22. Baer C, Bilkei G: Ultrasonographic and gross pathological findings in the mammary glands of weaned sows having suffered recidiving mastitis metritis agalactia. Reprod Domest Anim. 2005, 40(6):544-547.

23. Morkoc A, Backstrom L, Lund L, Smith AR: Bacterial endotoxin in blood of dysgalactic sows in relation to microbial status of uterus, milk, and intestine. J Am Vet Med Assoc 1983, 183:786-789.

24. Kemper N, Aschfalk A, Holler C: Campylobacter spp., Enterococcus spp., Escherichia coli, Salmonella spp., Yersinia spp., and Cryptosporidium oocysts in semi-domesticated reindeer (Rangifer tarandus tarandus) in Northern Finland and Norway. Acta Vet Scand 2006, 48:7.

25. Furniss SJ: Measurement of rectal temperature to predict mastitis, metritis and agalactia (MMA) in sows after farrowing. Prev Vet Med 1987, 5: 133-139.

26. Larsen I, Thorup F: The Diagnosis of MMA. 19th International Pig Veterinary Society Congress, Copenhagen, Denmark 2006:256.

27. Bertschinger HU, Bühlmann A: Absence of protective immunity in mammary glands after experimentally induced coliform mastitis. II International Pig Veterinary Society Congress Lausanne, Switzerland 1990:175.

28. Persson A, Pedersen Morner A, Kuhl W: A long-term study on the health status and performance of sows on different feed allowances during late pregnancy. II. The total cell content and its percentage of polymorphonuclear leucocytes in pathogen-free colostrum and milk collected from clinically healthy sows. Acta Vet Scand 1996, 37:279-291.

29. De Vliegher S, Laevens H, Devriese LA, Opsomer G, Leroy JLM, Barkema HW, de Kruif A: Prepartum teat apex colonization with Staphylococcus chromogenes in dairy heifers is associated with low somatic cell count in early lactation. Vet Microbiol 2003, 92:245-252.

30. Devriese LA, De Keyser H: Prevalence of different species of coagulase-negative streptococci on teats and milk samples from dairy cows. J Dairy Res 1979, 47:155-158.

31. Gerjets I, Kemper N: Coliform mastitis in sows: a review. Swine Health Prod 2009, 17:97-105.

32. Kobera R: Vergleichende Prüfung der klinischen Wirksamkeit von Cefquinom und Enrofloxacin bei der Behandlung des Mastitis-Metritis-Agalaktie-Komlexes der Sau. Dr-Thesis University of Leipzig; 2000.

33. Pedersen Mörner A, Faris A, Krovacek K: Virulence determinants of Escherichia coli isolated from the milk of sows with coliform mastitis. Zentralbl Veterinarmed B. 1998, 45(5):287-295.

34. Persson $A$ : Clinical assessment of udder health status of sows at time of weaning with special reference to bacteriology and cytology in milk. Zentralbl Veterinarmed A. 1997, 44(3): 143-158.
35. Bertschinger HU, Pohlenz J, Hemlep I: Mastitis metritis agalactia syndrome (milk fever) in sows. II. Bacteriological findings in spontaneous cases. Schweiz Arch Tierheilkd 1977, I I 9:223-233.

36. Ross RF, Harmon RL, Zimmermann BJ, Young TF: Susceptibility of sows to experimentally induced Escherichia coli mastitis. Am $J$ Vet Res 1983, 44:949-954.

37. Armstrong $\mathrm{CH}$, Hooper $\mathrm{BE}$, Martin CE: Microflora associated with agalactia syndrome of sows. Am J Vet Res 1968, 29: I40I-I 407.

38. Martin CE: Status of the mastitis-metritis-agalactia syndrome of sows. J Am Vet Med Assoc 1970, 157:1519-1521.

39. Nachreiner RF, Ginther OJ: Induction of agalactia by administration of endotoxin (Escherichia coli) in swine. Am J Vet Res 1974, 35:619-622.

40. Mauch C, Bilkei G: The influence of prepartal bacteriuria on the reproductive performance of the sow. Dtsch Tierarztl Wochenschr. 2004, I II(4): 166-169.

4I. Waller CM, Bilkei G, Cameron RD: Effect of periparturient diseases accompanied by excessive vulval discharge and weaning to mating interval on sow reproductive performance. Aust Vet J. 2002, 80(9):545-549.
Publish with BioMed Central and every scientist can read your work free of charge

"BioMed Central will be the most significant development for disseminating the results of biomedical research in our lifetime. "

Sir Paul Nurse, Cancer Research UK

Your research papers will be:

- available free of charge to the entire biomedical community

- peer reviewed and published immediately upon acceptance

- cited in PubMed and archived on PubMed Central

- yours - you keep the copyright

Submit your manuscript here:

http://www.biomedcentral.com/info/publishing_adv.asp
BioMedcentral 